\title{
Legal regulation of property insurance and law enforcement problems
}

\author{
Natalia Olegovna Kurchinskaya-Grasso ${ }^{1 *}$, Elena Petrovna Goryacheva ${ }^{2}$, Igor Viktorovich \\ Popov $^{3}$, Anastasia Viktorovna Abramova ${ }^{2}$, and Viacheslav Aleksandrovich Pechkurov ${ }^{2}$ \\ ${ }^{1}$ International Academy of Business and New Technologies (MUBiNT), Department of \\ Jurisprudence, Yaroslavl, Russia \\ ${ }^{2}$ Moscow University of Finance and Law, Department of Civil Law Disciplines, Moscow, Russia \\ ${ }^{3}$ Moscow University for Industry and Finance "Synergy", Department of Law Disciplines, Moscow, \\ Russia
}

\begin{abstract}
In the context of modern economic and legal reality, property insurance plays an important role in civil-law relations. For the present, Russian citizens, individual entrepreneurs and commercial entities witness an increasing need for a firm guarantee of protection of property interests linked with performing different types of activities and as well with maintaining a certain standard of living. Analysis of legislation in force reveals some gaps in the legal regulation of insurance institutions as a whole as well as a property insurance contract in particular, that conditions much judicial conflict and occurrence of errors in law enforcement that impact negatively on the protection of legal rights and interests of insurance relations participants. Legal research of law in force, theoretical understanding and relevant judicial practice in the matters of property insurance regulation along with possible identification of existing problems and formulation of proposals on legislation improvement. The methodological base for the present research is represented by a set of general scientific and specific scientific methods of research activities, including a historical method, a method of formal logic, a method of system analysis, a research method, a comparative legal method, a statistical method, a functional-structural method, methods of analysis and synthesis, a method of specification and as well an empirical and theoretical method, i.e. analogy, deduction. The authors suppose that provisions of Chapter 48 of the Civil Code of the Russian Federation must be completed with a separate norm on financial risk insurance as it is the case with property insurance, third-party liability insurance (damage liability insurance, contractual liability insurance) and entrepreneurial risk insurance in parallel with pointing out an object of insurance and cases when the conclusion of the mentioned contract is required. The authors prove the necessity to qualify the reinsurance contract as the property contract in line with other types thereof named in Article 929 of the Civil Code of the Russian Federation.
\end{abstract}

\footnotetext{
* Corresponding author: natgrasso@mail.ru
} 
Keywords: insurance activity, insurance relations, property insurance, reinsurance

\section{Introduction}

The higher impact of natural disasters and manmade disasters on all the spheres of social life as well as risky production encourage a new mechanism - property insurance. Insurance is one of the reliable forms to protect the subject's interests aimed at restoration of its property status. Anticipatory insurance - which the main function is to protect an insured person's interests via performing money payments to an affected person (a beneficiary party) by an insurance company - may restore an affected person's property status.

Nowadays property insurance as a type of insurance in whole plays an important multifaceted role in civil-law transactions. It is not only a substantial element of the state financial system as a whole, providing continuity of social production that depends on unfavorable phenomena and events, but also is a guaranty of the population social protection and also a factor stabilizing investments in the economy [1].

\section{Results}

From the authors' point of view, insurance in general and property insurance, in particular, may be categorized as "service". More specifically, this institution is related to a special type of service, for example, to insurance protection services. Services provided by the insurer (insurance protection) reveal three facets: material, legal and economic. A legal aspect finds itself reflected in the presence of the insurance commitment itself arising from the conclusion of an insurance contract by an insurance company and an insured person.

From the legislator's perspective, a property insurance contract's substantial conditions which require to be agreed to qualify a contract as concluded comprise the object insured, the insurable event characteristics, the insurance premium rate and the contract duration. However, the authors believe that a contradictory problem of determining the insured amount under a contract needs to be certainly resolved. It is more reasonable to change the wording of Article 947 of the Civil Code of the Russian Federation as it is just this article that allows parties' independent determination of the insured amount without regard to the actual value of the very object of insurance protection. In this context the content of point 2 of article 947 of the Civil Code of the Russian Federation must be amended as follows, excluding the phrase "unless otherwise provided in the insurance contract": "when insuring the property and entrepreneurial risk, the insured amount must not exceed their actual value". The use of such wording only eliminates the contradictions between point 1 of Article 951 of the Civil Code of the Russian Federation and point 2 of Article 947 of the Civil Code of the Russian Federation.

In the provisions of Article 951 of the Civil Code of the Russian Federation the legislator, when protecting insurance companies' interests, prohibits insuring property (entrepreneurial risk) over the actual value, regarding as null and void any contract in respect of the insured amount exceeding the insurable value. Nevertheless, the provisions of Article 947 of the Civil Code of the Russian Federation interpret the insured amount's determination in a more dispositive manner, allowing parties' self-performed calculation of the insured amount. To address the mentioned conflict, it is reasonable to improve the wording of just Article 947 of the Civil Code of the Russian Federation that enables the parties to fix the insured amount in an insurance contract without regard to the actual value of the property. 
Russian legislation directly refers to insurance to financial services, considering them to comprise also insurance services along with banking services, services provided in the securities market and linked with attracting and hosting monetary funds. In the literature property insurance linked with entrepreneurial activity is usually named industrial insurance, opposing it to consumption insurance [2].

Thus, a property insurance contract as a generic term comprises not only the contracts named in the Civil Code of the Russian Federation united on the basis of providing insurance of property interests.

\section{Discussion}

As it is known, the occurrence of the insured event must not depend on the actions of the insured person him/herself, otherwise, insurance claims are not validated due to that the fact of an unfavorable event's occasionality matters. But even despite the above-mentioned facts, the nature of relations arising between the insurer and the insured person is profitable for both parties under the insurance contract [3].

The object of insurance protection - the property itself - must be estimated in monetary terms, secondly, the insured person or another person whose interests are insured must be directly interested in preserving its integrity, i.e. without any damage or its total loss [4]. The doctrine reasonably notes that, along with the category "property", third party liability and entrepreneurial risk are as well subject to property insurance. The compensatory nature of the property insurance contract serves as its distinction [5, p. 134].

A required condition for performing insurance, i.e. concluding the mentioned contract, is the fact of the existing property interest of the insured person or the third party that is directly linked with risk of loss (destruction), shortage or damage of property. The Civil Code of the Russian Federation qualifies the third-party liability insurance contract as a kind of property insurance contract. However, as many authors believe, when using property status criterion as a base to distinguish types of insurance, it is rather complicated to qualify the third party liability insurance as a kind of property insurance. For example, I.A. Mitrichev considers that it is possible to distinguish the third party liability insurance on the basis of some other criterion but not the property status [6]. In this case, the insurance institution must be subdivided into the insurance of responsibility and insurance of irresponsibility. In support of this point of view V.B. Gomellya, D.S. Tulenty points out that as far as third party liability is not a kind of property but a kind of legal relationship, thus, it cannot be referred to as types of property insurance [7].

The judicial practice manifests no final position on the possibility to use contractual liability insurance as means to secure the performance of an obligation [8]. Contractual liability insurance comprises some accessory element in relation to the contract [9]. When concluding the contract of contractual liability insurance, it is a risk of liability of the insured person him/herself that is subject to insurance, thus, the concluded contract which provisions do not meet this requirement is qualified as null. Interest in appropriate fulfillment of the contractual obligation is considered as object of insurance in terms of such a contract [10].

The authors should agree that the insurance contract, when completed with a franchise clause, helps the insurer to control the amounts of the insurance payment and to reduce costs of settling insurable events [11].

\section{Conclusion}

It is defined that in our country the insurance institution is mostly regulated by civil and special legislation. The Civil Code of the Russian Federation includes the provisions that 
regulate just contractual relations between the insurer and the insured person. It should be recognized that in the Russian Federation entrepreneurial activity, if deprived of public support in insurance matters and of special public regulation, becomes unable to perform its economic and legal functions within the national model of conducting business [12].

Fulfillment of insurance entrepreneurial obligations is important for stability of civil-law transactions and business transactions [13]. Property insurance is a kind of paid rendering of services. The property insurance contract's subject is insurance protection performed by the insurer in the field of property interests of the insured person him/herself or other third party. From the authors' point of view, the provisions of Chapter 48 of the Civil Code of the Russian Federation (Articles 947 and 951) that regulates the procedure for the determination of the insured amount reveal some contradictions.

The doctrine reasonably points out "that it is necessary to achieve a balance in the legal regulation of civil, family and entrepreneurial relations, private and public entrepreneurial interests" [14]. In this context financial risk insurance is a separate type of property insurance. Financial risk insurance cannot be considered as a kind of entrepreneurial risk insurance as these two categories differ by their nature. To develop a uniform practice and remove confusion in interpreting the mentioned terms in the provisions of Article 929 of the Civil Code of the Russian Federation, it is required to enter the norms on financial risk insurance and qualify them as a kind of property insurance contract along with the contracts of property, third party liability and entrepreneurial risk insurance.

\section{References}

1. N.N. Bykova, B. of NGIEU, 12(67), 140 (2016)

2. A.N. Levushkin, Glava 4 - Dogovory v predprinimatelskoy deyatelnosti [Chapter 4 Contracts in entrepreneurial activity], in I.V. Ershova (ed.), Predprinimatelskoe Pravo: uchebnik [Entrepreneurial Law: manual] (Prospect, Moscow, 2020) https://doi.org/10.31085/9785392314362-2020-688

3. L.S. Larina, S.V. Sergeev, Property insurance against fire and other dangers (2007). Accessed on: December 25, 2020. [Online]. Available: http://www.vedco.ru/faq/detail.php?ID=1601064

4. I.K. Amirhanova, Mod. Probl. of Soc. and Hum. 2, 121-122 (2015)

5. A.M. Godin, S.V. Frumina, Strakhovanie [Insurance] (Dashkov i K, Moscow, 2015)

6. I.A. Mitrichev, Civil Law, 5, 11 (2015)

7. V.B. Gomellya, D.S. Tulenty, Finance, 12, 40 (2005)

8. M.G. Stepin, Law and Econ. 8(378), 64-70 (2019)

9. N.V. Vasilenko, Leg. Issues of Real Estate 1, 8-13 (2020)

10. O.V. Korneeva, T.I. Lysenko, A.N. Tanaga, A.V. Chebunin, M.A. Belyaev, A.A. Tomtosov, S.A. Kotuhov, S.A. Slesarev, Kommentarii k glave 48 "Strakhovanie" Grazhdanskogo kodeksa Rossiiskoy Federacii (chast vtoraya) ot 26.01.1996 № 14-FZ (postateinyi) [Commentary to chapter 48 "Insurance" of the Civil Code of the Russian Federation (part two) dated on the 26.01.1996 No. 14-FZ (article-by-article)], Konsultant-Plyus [Consultant-Plus] (2017). Accessed on: December 20, 2020. [Online]. Available:

http://www.consultant.ru/cons/cgi/online.cgi?req=doc\&base $=$ CMB\&n=18384\#0600374 316999271

11. M.V. Kratenko, Russ. Law: Experience, Analysis, Practice, 9, 64 (2019) 
12. Y.G. Leskova, A.N. Levushkin, S.Yu. Morozov, V.V. Romanov, S.G. Poberezhny, L.E. Rakhmatullina, IJEBA 8, 700-709 (2020)

13. A.N. Levushkin, I.K. Kuzmina, Contemp. Law 2, 150-166 (2020)

14. A.N. Levushkin, Civ. Law, 2, 3-7 (2020). https://doi.org/10.18572/2070-2140-2020-23-7 